Disajikan pada Seminar Nasional dan Kongres Himpunan Pendidik dan Peneliti Biologi Indonesia, Mataram 30 September 2017

\title{
Hubungan Motivasi Belajar dengan Hasil Belajar Biologi Siswa Di SMP 21 Rendani Manokwari
}

\author{
Insar Damopolii, Paskalina Th. Lefaan, Melda Manga' \\ Universitas Papua, Manokwari \\ E-mail :i.damopoli@unipa.ac.id (correspondence author)
}

\begin{abstract}
Abstrak
Penelitian ini bertujuan untuk mengetahui hubungan antara motivasi belajar dengan hasil belajar siswa pada mata pelajaran biologi di Kelas VII SMP Negeri 21 Rendani Kabupaten Manokwari. Metode dalam penelitian ini adalah ex post facto. Sampel dalam penelitian adalah seluruh siswa Kelas VII SMP Negeri 21 Rendani yang berjumlah 70 orang, dengan jumlah laki-laki 26 siswa dan perempuan 44 siswa. Data diperoleh melalui angket motivasi belajar dan dokumentasi hasil belajar. Uji validitas angket menggunakan korelasi product moment dan uji reliabilitas menggunakan rumus alpha. Analisis data menggunakan analisis regresi sederhana. Hasil penelitian menunjukkan bahwa motivasi belajar mempunyai hubungan dengan hasil belajar biologi siswa dan kontribusi motivasi belajar terhadap hasil belajar sebesar 25,9\%.
\end{abstract}

Kata kunci : Motivasi belajar, hasil belajar,

\begin{abstract}
This research aims to determine the correlation between learning motivation and student achievement on biology subjects at Class VII SMP Negeri 21 Rendani Manokwari Regency. The research method used ex-post facto. The sample in this research were all students of Class VII of SMP Negeri 21 Rendani which amounted to 70 students, with the number of male 26 students and female 44 students. Data were obtained through a questionnaire of learning motivation and documentation of student achievement. Test the validity of questionnaire using product moment correlation and reliability test using alpha formula. Data analysis used simple regression analysis. The results showed there are correlation learning motivation and student achievement and the contribution of learning motivation to student achievement of $25.9 \%$.
\end{abstract}

Keyword : Learning motivation, student achievement,

\section{PENDAHULUAN}

E-mail : i.damopoli@unipa.ac.id (correspondence author)

Disampaikan pada Seminar Nasional dan Kongres Himpunan Pendidik dan Peneliti Biologi Indonesia (HPPBI) 
Seorang siswa yang mempunyai tujuan untuk dicapainya memerlukan motivasi dalam dirinya agar tujuan yang diinginkannya dapat tercapai. Dengan adanya motivasi, seorang siswa akan melakukan apa saja untuk mencapai tujuannya yaitu memperoleh hasil belajar yang baik. Dengan demikian motivasi itu mempengaruhi adanya kegiatan. Menurut Fakhrudin (2009), seorang pendidik diharuskan untuk selalu memberikan semangat kepada anak didiknya untuk belajar dengan tekun, menghadapi kesusahan dengan senyum dan keterbatasan dengan semangat berubah.

Berdasarkan data hasil ujian akhir semester (UAS) pada Tahun Ajaran 2014/2015 (semester gasal dan genap), ratarata nilai biologi siswa kelas VII SMP Negeri 11 Manokwari berada di bawah nilai kriteria ketuntasan minimal $(\leq 60)$ yang dikeluarkan sekolah. Dengan rincian pada semester gasal 2014/2015, rata-rata nilai UAS siwa pada Kelas VIIA 8,33 (33 siswa), Kelas VIIB 12,03 (37 siswa) dan Kelas VIIC 16,35 (37 siswa). Rata-rata nilai UAS siswa pada semester genap pada Kelas VIIA 15,17 (35 siswa), Kelas VIIB 16,63 (33 siswa) dan Kelas VIIC 16,14 (32 siswa). Hasil belajar yang rendah pada siswa Kelas VII diduga disebabkan karena kurangnya motivasi dalam belajar. Hasil belajar siswa akan optimal jika ada motivasi yang tepat. Menurut Hamdu dan Agustina (2011) peningkatan hasil belajar siswa dipengaruhi oleh beberapa faktor, salah satunya adalah motivasi untuk belajar. Dengan adanya motivasi membuat siswa giat, ulet, dan tekun dalam proses belajar mengajar. Dorongan motivasi dalam belajar merupakan salah satu hal yang perlu dibangkitkan dalam upaya pembelajaran di dalam kelas.

Motivasi pada siswa Kelas VII sangat kurang hal ini juga dikarenakan karena siswa kurang aktif mengerjakan tugas rumah yang diberikan oleh guru maupun tugas yang seharusnya bisa dikerjakan di sekolah selain itu siswa jarang masuk kelas. Slameto (2015), menyatakan bahwa faktor-faktor yang mempengaruhi proses belajar adalah faktor yang berasal dari siswa atau disebut dengan faktor internal, dan faktor yang berasal dari luar dalam diri siswa yang disebut faktor eksternal. Faktor internal meliputi faktor psikologis (kondisi psikologis umum dan kondisi panca indera) dan faktor psikomotor (kecerdasan, minat, bakat, motivasi, kreatifitas dan kemampuan kognitif). Sedangkan faktor eksternal meliputi faktor lingkungan (lingkungan alami dan lingkungan sosial) dan faktor instrumental (program kurikulum, guru atau tenaga pengajar, dan fasilitas sekolah).

Biologi sebagai salah satu mata pelajaran di sekolah dapat memberikan peran dan pengalaman bagi siswa. Dalam pembelajaran biologi dilakukan dengan berbagai upaya, salah satunya melalui peningkatan motivasi belajar. Siswa dalam proses belajar akan memperoleh hasil belajar yang baik jika ada motivasi atau dorongan

\section{METODE PENELITIAN}

Penelitian dilaksanakan di SMP Negeri 21 Rendani Kabupaten Manokwari. 
Metode penelitian adalah ex post facto. Desain penelitian menggunakan desain sederhana yaitu:

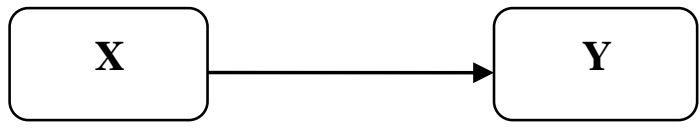

Ket:

$\mathrm{X}=$ Motivasi Belajar

$\mathrm{Y}=$ Hasil Belajar

Sampel dalam penelitian ini adalah seluruh siswa kelas VII berjumlah 70 siswa, dengan jumlah laki-laki 26 dan perempuan 44. Teknik pengumpulan data menggunakan angket dan dokumentasi hasil belajar. Uji validitas instrumen menggunakan korelasi Product moment dan reliabilitas menggunakan rumus Alpha. Analisis data menggunakan analisis regresi sederhana dengan syarat data berdistribusi normal. Uji normalitas data menggunakan one sample kolmogorov smimov.

\section{HASIL PENELITIAN DAN} PEMBAHASAN

Hasil uji normalitas data menggunakan One-Sample KolmogorovSmirnov, ditampilkan pada Tabel 1.

Tabel 1. Uji normalitas Data

\begin{tabular}{lll}
\hline & & Unstandardized Residual \\
\hline $\mathrm{N}$ & & 70 \\
Normal Parameters & Mean & 0,0000000 \\
& Std. Deviation & 20,39765015 \\
Most Extreme Differences & Absolute & 0,067 \\
& Positive & 0,067 \\
Test Statistic & Negative & $-0,066$ \\
Asymp. Sig. (2-tailed) & & 0,067 \\
\hline
\end{tabular}

Berdasarkan data pada Tabel 1, lanjut menggunakan regresi sederhana. menunjukkan bahwa data berdistribusi normal, Kontribusi motivasi belajar terhadap hasil dimana nilai sig lebih besar dari $\alpha(0,200>$ belajar ditampilkan pada Tabel 2 . $0,05)$. Sehingga data residual bisa dianalisi

Tabel 2. Kontribusi motivasi belajar terhadap hasil belajar

\begin{tabular}{lllll}
\hline Model & $\mathrm{R}$ & R Square & $\begin{array}{l}\text { Adjusted } \\
\text { Square }\end{array}$ & $\begin{array}{l}\text { R Std. Error of the } \\
\text { Estimate }\end{array}$ \\
\hline 1 & $0,509^{\mathrm{a}}$ & 0,259 & 0,248 & 20,547
\end{tabular}

Berdasarkan Tabel 2. Menunjukkan bahwa motivasi belajar memilki kekutan hubungan yang sedang dengan hasil belajar biologi siswa, hal ini ditunjukkan dengan nilai $\mathrm{R}$ sebesar 0,509. Sementara itu nilai R Square sebesar 0,259 yang berarti motivasil belajar memiliki kontribusi atau pengaruh sebesar $25,9 \%$ terhadap hasil belajar biologi siswa, sedangkan 74,1\% lainnya dipengaruhi oleh faktor lain di luar motivasi belajar.

Analisis regresi sederhana menggunakan ANOVA dengan ketentuan jika 
nilai signifikansi lebih kecil dari $\alpha=0,05$. Hasil

uji ANOVA ditampilkan pada Tabel 3.

Tabel 3. Hasil uji ANOVA motivasi belajar dengan hasil belajar

\begin{tabular}{lllllll}
\hline Model & & Sum of Squares & Df & Mean Square & F & Sig. \\
\hline 1 & Regression & 10028,375 & 1 & 10028,375 & 23,754 & $0,000^{\mathrm{b}}$ \\
& Residual & 28708,425 & 68 & 422,183 & & \\
& Total & 38736,800 & 69 & & & \\
\hline
\end{tabular}

Berdasarkan data pada Tabel 3 selanjutnya adalah uji koefisien regresi yang menunjukkan bahwa nilai sig adalah 0,000 ditampilkan pada Tabel 4.

yang menandakan bahwa model regresi dapat memprediksi hasil belajar siswa. Langkah

Tabel 4. Hasil Uji Koefisien Regresi

\begin{tabular}{lllllll}
\hline & & \multicolumn{2}{l}{$\begin{array}{l}\text { Unstandardized } \\
\text { Coefficients }\end{array}$} & \multicolumn{2}{l}{$\begin{array}{l}\text { Standardized } \\
\text { Coefficients }\end{array}$} & \\
\cline { 3 - 5 } Model & & $\mathrm{B}$ & Std. Error & Beta & T & Sig. \\
\hline 1 & $\begin{array}{l}\text { (Constant) } \\
\text { Motivasi }\end{array}$ & $-48,127$ & 18,980 & & $-2,536$ & 0,014 \\
& Belajar & 0,622 & 0,128 & 0,509 & 4,874 & 0,000 \\
& & & & & &
\end{tabular}

Berdasarkan data pada Tabel 4 menunjukkan bahwa nilai sig 0,014 lebih kecil dari $\alpha=0,05$ yang menandakan bahwa koefisien regresi adalah signifikan. Persamaan regresinya adalah $\hat{Y}=-48,127+0,622 X$. Model regresi menunjukkan bahwa setiap kenaikan satu unit motivasi belajar maka akan meningkat pula hasil belajar siswa pada ujian tengah semester sebesar 0,622 unit pada konstanta -48,127. Artinya semakin baik motivasi belajar siswa maka hasil belajarnya juga akan semakin tinggi, sebaliknya semakin rendah motivasi belajar siswa maka hasil belajarnya juga menurun.

Motivasi memiliki hubungan dengan hasil belajar. Hasil belajar siswa akan baik dikarenakan memiliki motivasi yang kuat dalam diri mereka. Hasil penelitian ini sejalan dengan dengan penelitian Firmansyah (2009) menyimpulkan bahwa terdapat hubungan positif antara motvasi dan hasil belajar pada pendidikan jasmani. Motivasi belajar siswa tidaklah sama, tetapi berbeda beda. Ada siswa yang memiliki motivasi yang tinggi ada siswa yang memiliki motivasi yang rendah. Hal ini ditunjukkan dengan skor angket motivasi yang berbeda dimana skor minimum 107 dan skor maksimum 182. Menurut Daskalovska et. al (2012) bahwa semua pembelajar di dalam kelas tidak memiliki jenis dan level motivasi yang sama. Beberapa pembelajar memiliki motivasi yang kuat, yang lain membutuhkan seorang yang membangkitkan motivasi dan bahkan ada yang tidak memiliki motivasi.

Motivasi merupakan dorongan dari dalam diri dan dari luar diri seorang siswa yang membuat siswa terdorong untuk melakukan sesuatu dalam mencapai tujuan yang ingin dicapai. Tujuan siswa dalam belajar adalah memperoleh hasil belajar yang baik. Motivasi memiliki kontribusi atau pengaruh terhadap hasil belajar. Hasil penelitian menunjukkan 
bahwa motivasi belajar mempunyai kontribusi sebesar 25,9\%. Hasil penelitian ini sejalan dengan penelitian yang telah dilakukan oleh Inayah dkk (2013) dan Lee (2010) yang menyimpulkan bahwa motivasi memiliki pengaruh atau kontibusi terhadap hasil belajar.

\section{KESIMPULAN}

Kesimpulan dalam penelitian ini adalah terdapat hubungan motivasi belajar dengan hasil belajar biologi siswa SMP 21 Rendani Kabupaten Manokwari. Motivasi memiliki kontribusi atau pengaruh terhadap hasil belajar. Semakin tinggi motivasi belajar maka hasil belajar akan semakin baik.

\section{DAFTAR PUSTAKA}

Daskalovska, N., Gudeva, L. K., \& Ivanovska, B. (2012). Learner Motivation and Interest. Procedia - Social and Behavioral Sciences, 46, 1187-1191.

Fakhrudin, A. U. (2009). Menjadi Guru Favorit. Jogjakarta: Diva Pres

Firmansyah, H. (2011). Hubungan Motivasi Berprestasi Siswa Dengan Hasil Belajar Pendidikan Jasmani. Jurnal Pendidikan
Jasmani Indonesia, 6(1), 30-33.

Hamdu, G., \& Agustina, L. (2011). Pengaruh Motivasi Belajar Siswa terhadap Pestasi Belajar IPA Di Sekolah Dasar (Studi Kasus terhadap Siswa Kelas IV SDN Tarumanagara Kecamatan Tawang Kota Tasikmalaya). Jurnal Penelitian Pendidikan, 12(1), 81-86.

Inayah, R. (2013). Pengaruh Kompetensi Guru, Motivasi Belajar Siswa, dan fasilitas Belajar Terhadap Prestasi Belajar Mata Pelajaran Ekonomi pada Siswa Kelas XI IPS SMA Negeri 1. Jurnal Pendidikan Insan Mandiri. 1(1), 1-13

Lee, I.-C. (2010). The Effect of Learning Motivation, Total Quality Teaching and Peer-Assisted Learning on Study Achievement: Empirical Analysis from Vocational Universities or Colleges' students in Taiwan. The Journal of Human Resource and Adult Learning, 6(December), 56-73.

Slameto. (2015). Belajar dan Faktor-faktor Yang Mempengaruhi. Jakarta: Rineka Cipta 